\title{
PERAN PENGAWASAN BADAN PERMUSYAWARATAN DESA (BPD) DALAM PENGELOLAAN ANGGARAN PENDAPATAN DAN BELANJA DESA (APBDES) DIMASA PANDEMI COVID-19
}

\author{
Studi kasus di Desa Tamanasri Kecamatan Pringkuku Kabupaten Pacitan \\ Navy Sagita Pertiwi \\ S1 Ilmu Administrasi Negara, Fakultas Ilmu Sosial dan Hukum, Universitas Negeri Surabaya \\ Email: npertiwi09@gmail.com \\ Muhammad Farid Ma'ruf \\ S1 Ilmu Administrasi Negara, Fakultas Ilmu Sosial dan Hukum, Universitas Negeri Surabaya \\ Email: muhammadfarid@unesa.ac.id
}

\section{Abstrak}

Undang-Undang No. 6 Tahun 2014, Badan Permusyawaratan Desa (BPD) merupakan lembaga yang melaksanakan fungsi pemerintahan, keanggotaannya merupakan wakil dari penduduk desa berdasarkan keterwakilan wilayah dan ditetapkan secara demokratis. Salah satu terkait fungsi BPD yaitu menjalankan fungsi pengawasan terhadap pengelolaan Anggaran Pendapatan dan Belanja Desa (APBDes). Dalam kurun satu tahun, APBDes memuat pengeluaran desa serta sumber pendapatan desa. Pengawasan pengelolaan APBDes oleh BPD sangat diperlukan, tujuannya ialah perputaran dana yang terjadi dalam pemerintahan desa dapat dipertanggung jawabkan keabsahan data laporannya. Pengawasan pengelolaan APBDes oleh BPD tersebut menjadi lebih urgent akibat adanya pandemi Corona Virus Disease-19 (Covid-19). Pasalnya, saat pandemi Covid-19 telah dilakukan perubahan terhadap APBDes yang sebelumnya telah ditetapkan. Menggunakan jenis penelitian deskriptif serta metode pendekatan kualitatif. Teknik pengumpulan data yaitu wawancara terbuka-terstruktur, observasi, dokumentasi. Teknis analisis data dalam penelitian: Model Spradley, sumber datanya yaitu data primer dan sekunder. Hasil penelitian, BPD Tamanasri telah menjalankan peran pengawasannya dengan baik dalam roda pemerintahan Desa Tamanasri. Terbukti, selama periode tahun anggaran 2020 yang mengalami situasi pandemi Covid-19, pembuatan perubahan Perdes APBDes dilakukan dengan pertimbangan yang matang untuk kepentingan masyarakat desa dan Bantuan Langsung Tunai Dana Desa (BLT-DD) I, II, III telah tersalurkan dengan semestinya melalui survei terlebih dahulu oleh tim survei BLT-DD.

Kata kunci: Peran BPD, Pengawasan, Pengelolaan APBDes.

\section{Abstract}

Law No. 6 of 2014, Village Consultative Agency (BPD) is an institution that carries out government functions, its membership is representative of the villagers based on regional representation and determined democratically. One of the related functions of BPD is to carry out the supervisory function of the management of village budget (APBDes). In one year, APBDes contain village expenditures as well as village revenue sources. Supervision of APBDes management by BPD is very necessary, the goal is the turnover of funds that occur in the village government can be accounted for the validity of the report data. Supervision of APBDes management by BPD becomes more urgent due to the Corona Virus Disease-19 (Covid-19) pandemic. Because, during that pandemic, changes have been made to APBDes that have previously been determined. Using descriptive research types as well as qualitative approach methods. Data collection techniques are open-structured interviews, observations, documentation. Technical data analysis in the study: Spradley model, the data source is primary and secondary data. The result of the research, BPD Tamanasri has performed its supervisory role well in the government wheel of Tamanasri Village. Evidently, during the period of fiscal year 2020 which experienced the Covid-19 pandemic situation, the making of changes in APBDes Perdes was carried out with careful consideration for the benefit of the village community and Cash Direct Assistance Village Fund (BLT-DD) I, II, III has been distributed properly through a survey in advance by BLT-DD survey team.

Keyword: Role of BPD, Supervision, Management of APBDes.

\section{PENDAHULUAN}

Undang-Undang tentang Desa No. 6 Tahun (Undang-Undang Republik Indonesia No 6 Tahun 2014 Tentang Desa, 2014) Pasal 1 menjelaskan terkait pengertian desa, yaitu kesatuan masyarakat hukum yang memiliki batas wilayah yang berwenang untuk mengatur dan mengurus urusan pemerintahan, kepentingan masyarakat setempat berdasarkan prakarsa masyarakat, hak asal usul, dan atau hak tradisional yang 
diakui dan dihormati dalam sistem pemerintahan Negara Kesatuan Republik Indonesia (NKRI). Kewenangan desa menurut pandangan Watts dkk (2019:3) yaitu untuk menjaga keutuhan persatuan serta stabilitas NKRI, memperbaiki kualitas hidup, menjalankan demokrasi, menjalankan pemberdayaan masyarakat dan memberikan pelayanan dasar. Adanya wewenang tersebut menjadikan desa memiliki otonomi sendiri yang disebut otonomi desa, yang mana memiliki unsur-unsur penting yang perlu diperhatikan yakni; 1) Masyarakat desa yang bersangkutan, masih menaati adanya adat tertentu yang mengikat; 2) Tanah, pusaka, dan kekayaan desa; 3) Berbagai sumber pendapatan yang dimiliki desa; 4) Pemerintah desa yang dipilih oleh dan dari kalangan masyarakat desa yang bersangkutan, yang sebagai alat desa memegang fungsi "mengurus"; 5) Lembaga atau badan "perwakilan" atau permusyawaratan, yang sepanjang penyelenggaraan urusan rumah tangga desa memegang fungsi "mengatur" (Lonthor, 2018:29).

Mengatur penyelenggaraan pemerintahan desa, suatu desa selalu diikuti tindakan pengawasan. Pengawasan itu sendiri merupakan suatu usaha yang dilakukan dengan mengamati berlangsungnya aktifitas operasional yang bertujuan menjamin bahwa aktifitas tersebut sesuai dengan konsep yang telah ditentukan sebelumnya (Samsirin, 2015:343). Selain itu, konsep pengawasan terhadap penyelenggaraan pemerintahan desa telah diatur dalam UU No 6 Tahun 2014 pasal 12, yang berbunyi:

1. Pemerintah, Pemerintah Daerah Provinsi, dan Pemerintah Daerah Kabupaten/Kota membina dan mengawasi penyelenggaraan Pemerintahan Desa,

2. Pemerintah, Pemerintah Daerah Provinsi, dan Pemerintah Daerah Kabupaten/ Kota dapat mendelegasikan pembinaan dan pengawasan kepada perangkat daerah, meliputi: Melakukan Evaluasi Dan Pengawasan Peraturan Desa; Mengawasi Pengelolaan Keuangan Desa dan pendayagunaan Aset Desa; Melakukan pembinaan dan Pengawasan penyelenggaran Pemerintahan Desa; terakhir Merekomendasikan pemberian sanksi atas penyimpangan yang dilakukan oleh Kepala desa sesuai dengan ketentuan peraturan perundang-undangan.

Mengacu pada Undang-Undang Nomor 6 Tahun (Undang-Undang Republik Indonesia No 6 Tahun 2014 Tentang Desa, 2014) tentang Desa Pasal 55 disebutkan bahwa BPD mempunyai fungsi yaitu: 1) membahas dan menyepakati Rancangan Peraturan Desa bersama Kepala Desa; 2) menampung dan menyalurkan aspirasi masyarakat desa; dan 3) melakukan pengawasan kinerja kepala desa. Pada poin nomor tiga diatas dijelaskan BPD. Merujuk pada Peraturan Pemerintah Nomor 43 Tahun (2014) tentang Petunjuk Pelaksanaan Undang-
Undang Desa, pada Pasal 4 yaitu: Dalam melaksanakan tugas, kewenangan, hak, dan kewajibannya, kepala Desa wajib, yaitu: a) menyampaikan laporan penyelenggaraan pemerintahan desa setiap akhir tahun anggaran kepada bupati/walikota; b) menyampaikan laporan penyelenggaraan pemerintahan desa pada akhir masa jabatan kepada bupati/walikota; c) menyampaikan laporan keterangan penyelenggaraan pemerintahan secara tertulis kepada Badan Permusyawaratan Desa setiap akhir tahun anggaran.

Adapun pembahasan lebih lanjut dijelaskan dalam Pasal 51 Peraturan Pemerintah (PP) No 43 Tahun 2014, yaitu kepala desa menyampaikan Laporan Keterangan Penyelenggaraan Pemerintahan Desa sebagaimana yang dimaksud dalam Pasal 4 poin ketiga sebelumnya yakni setiap akhir tahun anggaran kepada Badan Permusyawaratan Desa secara tertulis paling lambat 3 (tiga) bulan setelah berakhirnya tahun anggaran. Laporan Keterangan Penyelenggaraan Pemerintahan Desa tersebut paling sedikit memuat pelaksanaan peraturan desa. Selain itu dalam pasal 51 PP No 43 Tahun 2014, tersebut juga menjelaskan bahwa Laporan Keterangan Penyelenggaraan Pemerintahan Desa digunakan oleh BPD untuk mengawasi kinerja kepala desa. Selain itu BPD beserta pemerintah desa dapat saling bersinergi hal ini dikarenakan keduanya merupakan mitra kerja dalam pemerintahan desa, sehingga diharapakan keduanya dapat saling mendukung dalam musyawarah terkait pembangunan di desa (Mardiyah \& Nurlinah, 2019:109). Pemerintah desa dan BPD diharapkan dapat memajukan suatu desa dengan memberikan arahan, saran maupun pengawasan pada penyusunan dan penggunaan Anggaran Pendapatan dan Belanja Desa (APBDes) dalam menetapkan peraturan pemerintah desa (Pangestika, 2019:127). Oleh Puspitasari dan Ma'ruf (2018) dijelaskan APBDes sendiri merupakan Peraturan Desa (Perdes) yang didalamnya terdapat pengeluaran desa serta memuat berbagai sumber penerimaan atau pendapatan desa, masing-masing dalam kurun waktu satu tahun.

Sejalan dengan fungsi tersebut, maka pengawasan BPD terhadap APBDes sangat diperlukan. Terlebih hingga kini terjadi pandemi Corona Virus Disease-19 (Covid-19), yang mana tidak hanya di Indonesia saja bahkan pandemi tersebut mewabah kepenjuru dunia. (KEMENKESRI, 2020) Pandemi ini berawal dari Badan Kesehatan Dunia/ World Health Organization (WHO) yang memberikan informasi pada tanggal 31 Desember di Wuhan, Provinsi Hubei, China terkait kluster pneumonia dengan etiologi yang tidak diketahui. Kasus tersebut pun terus berkembang hingga adanya laporan kematian dan terjadi di luar China. Pada tanggal 30 Januari 2020, WHO 
menetapkan Covid-19 sebagai Kedaruratan Kesehatan Masyarakat yang Meresahkan Dunia (KKMMD). Sedangkan di Indonesia pada tanggal 2 Maret 2020 tercatat 2 kasus konfirmasi Covid-19, hingga pertanggal 25 Juli 2020 tercatat 100.303 kasus positif.

Ditengah pandemi Covid-19 ini pemerintah pusat berinisiatif dalam membantu meringankan masyarakat yang terdampak Covid-19. Melalui Kementerian Keuangan Republik Indonesia, pemerintah pusat menyalurkan dana bantuan yang disebut Bantuan Langsung Tunai Dana Desa (BLT-DD). Hal ini dimuat dalam Peraturan Menteri Keuangan Republik Indonesia Nomor 156/PMK.07/2020 tentang Perubahan Ketiga Atas Peraturan Menteri Keuangan Nomor 205/PMK.07 /2019 tentang Pengelolaan Dana Desa, pada pasal 32A ayat 5 menjelaskan mengenai Besaran Bantuan Langsung Tunai Dana Desa (BLT-DD) ditetapkan sebesar: a) $\mathrm{Rp}$ 600.000,00 (enam ratus ribu rupiah) untuk bulan pertama sampai dengan bulan ketiga per keluarga penerima manfaat; b) Rp 300.000,00 (tiga ratus ribu rupiah) untuk bulan keempat sampai dengan bulan kesembilan per keluarga penerima manfaat. Selain itu kriteria calon keluarga penerima manfaat BLT Desa sebagaimana yang tertera dalam pasal 32 A ayat 3 Peraturan Menteri Keuangan Republik Indonesia Nomor 156 /PMK.07/2020,yakni: Pertama, Keluarga miskin atau tidak mampu yang berdomisili di desa bersangkutan; Kedua, Tidak termasuk penerima bantuan Program Keluarga Harapan (PKH), Kartu Sembako, dan Kartu Pra Kerja.

Dari sinilah urgensi peran pengawasan BPD terhadap APBDes dimasa pandemi Covid-19 sangat diperlukan. Hal ini dikarenakan tujuan dari pengawasan yaitu untuk menyelesaikan tiga perkara utama, yakni penyeimbang tujuan (kerja sama), kapasitas dalam penyesuaian lingkungan dan integrasi (koordinasi) (Dekker dkk., 2018:5). Lebih lanjut terkait proses pengawasan dijelaskan oleh Terry dalam buku Principles of Manajemen (Sukarna, 2011:116) yakni:

a) Determining the standard or basis for control (menentukan standar atau dasar bagi pengawasan);

b) Measuring the performance (mengukur pelaksanaan);

c) Comparing performance with the standard and ascerting the difference, it any (membandingkan pelaksanaan dengan standard dan temukan jika ada perbedaan);

d) Correcting the deviation by means of remedial action (perbaiki penyimpangan dengan cara-cara tindakan yang tepat).
Selain itu inti dari tugas BPD dalam pengawasan APBDes yakni melakukan pengawasan terhadap pemerintah desa sebagai pihak yang melakukan atau menjalankan tersebut (Puspitasari \& Ma'ruf, 2018). Sedangkan oleh Roza dan Laurensius (2017) menjelaskan mengenai kegiatan peran pengawasan keuangan oleh BPD, berikut diantarnya:

a. Melakukan pengendalian keuangan: yakni BPD merupakan unsur dari penyelenggaraan pemerintah desa, maka Rencana Pembangunan Jangka Menengah Desa (RPJMDes) yang telah dirancang oleh kepala desa tersebut BPD-lah yang melakukan pengawasan. Sehingga terjalinnya hubungan kerjasama antara BPD dan kepala desa.

b. Pengawasan keuangan: BPD diharapkan dapat melaksanakan tugas, pokok, dan fungsi (tupoksi) terkait pengawasannya dalam hal kebijakan yang telah ditetapkan dan disepakati secara bersama yakni RPJMDes dan dapat memastikan pelaksanaannya di lapangan (sudah sesuai atau belum) dengan yang dirumuskan dalam RPJMDes.

c. Pemantauan: ketika implementasi program yang terdapat di RPJMDes tengah berjalan, BPD hanya terlibat didalamnya guna memantau seperti apa berlangsungnya perundingan mengenai alokasi dana desa tersebut, dan jika diperlukan BPD memberikan masukan.

d. Evaluasi: pada saat melaksanakan kewajibannya, BPD harus membuat penilaian pada kegiataan yang telah dilaksanakan, maka keunggulan dan kelemahan dapat segera diketahui sehingga dapat dijadikan bahan evaluasi untuk kedepannya agar menjadi lebih maksimal baik itu dari segi keefektifan maupun keefisienannya.

e. Supervisi: Dalam hal ini BPD diharapkan dapat menerapkan konsep supervisi pada saat melaksanakan tupoksinya, sehingga dapat mencegah terjadinya penyimpangan sekaligus dapat melakukan tindakan perbaikan kebijakan yang akan berjalan dengan demikian dapat membuahkan hasil yang maksimal.

Perda Kabupaten Pacitan No 3 Tahun (2019), tentang Badan Permusyawaratan Desa (BPD) menjelaskan mengenai bagaimana pengawasan BPD berlangsung, yaitu 1) BPD melakukan pengawasan melalui monitoring dan evaluasi pelaksanaan tugas Kepala Desa, 2) Monitoring dan evaluasi sebagaimana dimaksud ayat (1) terhadap perencanaan, pelaksanaan dan pelaporan penyelenggaran Pemerintahan Desa. Berikut ini telah disajikan bagan alur monitoring yang dilakukan oleh BPD : 


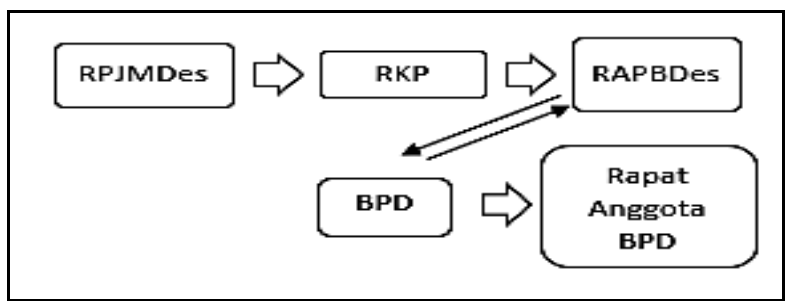

Gambar 1. Skema Peran Pengawasan

(Sumber: Perda Kabupaten Pacitan No 3 2019)

Dari uraian di atas membuktikan bahwa pengawasan dalam pengelolaan APBDes oleh BPD sangat penting, hal ini bertujuan agar perputaran dana yang terjadi dalam pemerintahan desa dapat dipertanggung jawabkan keabsahan data laporannya. Ditambah pada masa pandemi Covid-19 ini perubahan terkait APBDes pasti terjadi. Perubahan APBDes ini diperbolehkan, apabila: a) Suatu desa dihadapkan dalam kondisi yang mengakibatkan jenis belanja dilakukan pergeseran; b) Suatu desa dihadapkan dalam kondisi yang mengakibatkan sisa lebih perhitungan anggaran (SilPA) pada periode tahun anggaran sebelumnya; c) Adanya penjumlahan dan atau pengurangan dalam pendapatan desa pada tahun yang sedang berlangsung; d) Adanya suatu peristiwa khusus, yakni krisis politik, krisis ekonomi, bencana alam, dan atau kerusuhan sosial yang sifatnya berkepanjangan; e) Adanya modifikasi yang bersifat fundamental karena kebijakan Pemerintah dan Pemerintah Daerah (Rozuqi, 2020).

Didalam menjalankan perannya tersebut BPD dituntut berpedoman pada asas Pengelolaan Keuangan Desa yang mana tertuang pada pasal 2 Permendagri No. 20 Tahun (2018) tentang Pengelolaan Keuangan Desa menyatakan keuangan desa dikelola berdasarkan atas beberapa asas diantaranya yaitu: transparan, akuntabel, partisipatif, serta tertib dan disiplin anggaran. Disebutkan dalam sebuah penelitian jika kualitas pelayanan publik biasanya dinilai dari segi kinerjanya terhadap mandat atau intruksinya, terutama diukur dari titik akuntabilitas, transparansi, efisiensi dan efektifitas (Polat \& Alkan, 2020:9). (Rois \& Fanida, 2016) Akuntabilitas yaitu dalam pelaksanaan organisasi terdapat tujuan dan target yang telah ditentukan sebelumnya dan dalam setiap tindakan dapat dipertanggungjawabkan, baik itu menghasilkan keberhasilan maupun kegagalan. UNDP (1997) menjelaskan mengenai transparansi ialah dibangun atas dasar kebebasan tanpa pandang bulu, sedangkan efisiensi dan efektifitas adalah melakukan terhadap sumber daya publik yang dilakukan secara berdaya guna (efisien) dan berhasil guna (efektif) (Rois dan Fanida, 2016).

Akuntabilitas, transparansi, efisiensi dan efektifitas dalam pemerintah desa perlu ditingkatkan. Pasalnya, penyelewengan terhadap APBDes masih kerap terjadi di sejumlah daerah Indonesia yang mana dari tahun ke tahun ditemukannya kasus terkait bentuk penyelewengan terhadap Dana APBDes. Sehingga yang terjadi dilapangan tidak sesuai dengan ekspektasi. Hal tersebut terbukti mengenai catatan dari Indonesia Corruption Watch (ICW) yang dilansir dari (Ihsanuddin, 2018), terhitung pada tahun 2015 hingga awal tahun 2018 kasus korupsi terkait dana desa yang telah direncanakan dalam APBDes mengalami peningkatan. ICW pun mendata di provinsi Jawa Timur telah mencapai sejumlah 41 kepala desa yang melakukan korupsi dana desa. Laporan terbaru yang diperoleh dari data ICW tahun 2019 melalui laman web telah tercatat di sektor anggaran desa sebesar 46 kasus korupsi dari 271 kasus korupsi. Kerugian negara pun tercatat hingga Rp 32,3 Miliar. Kemudian Pratama (2019) dalam laman webnya disebutkan bahwa Indonesia Corruuption Watch mencatat jumlah kepala desa (kades) di Jawa Timur pada tahun 2016 terdapat 3 orang, 2017 sebanyak 15 orang, tahun 2018 tercatat 13 orang, dan pada 2019 masih dalam pendataan kala itu.

Desa Tamanasri Kecamatan Pringkuku turut menyumbangkan angka korupsi dana desa di Jawa Timur pada tahun 2017. Tercatat tepat pada bulan Oktober 2017 silam telah dilakukan penyidikan tim tindak pidana korupsi, yang terdapat bukti yang menyatakan jika pada akhir 2015 rekening khas desa sudah tidak ada akan tetapi tidak ada bukti pekerjaan fisik atau kegiatan yang digunakan untuk pembangunan desa terhadap pengelolaan APBDes yang dikerjakan di desa tersebut. Berikut rincian anggaran dana yang telah diselewengkan antara lain Rp 944.639.362 yang dibagi menjadi Alokasi Dana Desa (ADD), Dana Bagi Hasil Pajak Daerah (DBHPD) Bantuan Keuangan (BK) dan Pendapatan Asli Daerah (PAD), penjelasan tersebut disampaikan oleh Kasat Reskrim Polres Pacitan AKP Imam Buchori (Sumbo, 2018). Hal inilah oleh Abas (2017) diungkapkan bahwa bukti terjadinya degradasi moral dalam penyelenggaraan pemerintahan maupun unsur kepentingan yang mengakibatkan praktik korupsi, sehingga mengakar ditingkat desa. Adanya praktik korupsi tersebut dijelaskan oleh Permana dkk (2017), disebabkan adanya tekanan keuangan maupun non keungan yang mana merupakan tekanan pribadi dan organisasi yang dirasakan oleh oknum aparat yang mana dapat memicu kemungkinan besar dalam melakukan praktik korupsi maupun kecurangan lainnya (Nitsae dkk., 2020). Disisi lain, adanya pandemi Covid19 yang juga turut menjadi perhatian dalam seluruh lapisan masyrakat, terlebih di Kabupten Pacitan juga terdapat korban dari Covid-19 ini berikut telah tersajikan data pasien Covid-19 dengan keterangan kasus konfirmasi, sembuh, dan meninggal di Kabupaten Pacitan, yang merupakan kabupaten dari Desa 
Tamanasri yang dijadikan sebagai lokasi penelitian ini, berikut data tersebut:

Tabel 1. Data Kasus Konfirmasi, Sembuh dan Meninggal akibat Covid-19

\begin{tabular}{|l|c|c|c|c|c|c|c|c|c|}
\hline \multirow{2}{*}{ Keterangan } & \multicolumn{7}{|c|}{ Bulan } \\
\cline { 2 - 9 } & Apr & Mei & Juni & Jul & Agst & Sep & Okt & Nov & $\begin{array}{c}\text { Des } \\
(9 / 12 / \\
2020\end{array}$ \\
\hline $\begin{array}{l}\text { Kasus } \\
\text { Konfirmasi }\end{array}$ & 4 & 10 & 10 & 32 & 28 & 25 & 139 & 112 & 68 \\
\hline Sembuh & 0 & 2 & 9 & 35 & 29 & 21 & 94 & 117 & 43 \\
\hline Meninggal & 0 & 0 & 1 & 1 & 0 & 1 & 4 & 4 & 4 \\
\hline
\end{tabular}

Sumber: Satuan Gugus Tugas Covid-19 Kabupaten Pacitan $(09 / 12 / 2020)$

Sedangkan dibawah ini merupakan data terkait kasus Covid-19 pada masyarakat Desa Tamanasri, yang mana sebagai fokus lokasi penelitian ini:

a. Pasien Positif Covid-19 berjumlah 2 orang

b. Karantina mandiri untuk keluarga pasien positif, berjumlah 2 KK (Kartu Keluarga)

c. Kartina mandiri masyarakat gejala Covid-19, berjumlah 350 orang.

(Sumber: Dokumen Desa Tamanasri (Nov 2020))

Selain itu, dalam penyelenggaraan pemerintahan Desa Tamanasri yang disebabkan adanya bencana nonalam ini yang masih berkepanjangan hingga batas yang masih belum diketahui berakhirnya pandemi ini, maka pada tahun anggaran ini, Peraturan Desa (Perdes) Tamanasri Nomor 05 Tahun 2019 tentang Anggaran Pendapatan dan Belanja Desa tahun anggaran 2020 telah mengalami perubahan sejumlah tiga kali, berikut uraiannya: Perdes Tamanasri Nomor 4 Tahun 2020 tentang Perubahan Pertama Anggaran Pendapatan dan Belanja Desa tahun anggaran 2020.Perdes Tamanasri Nomor 6 Tahun 2020 tentang Perubahan Kedua Anggaran Pendapatan dan Belanja Desa tahun anggaran 2020.Dan Perdes Tamanasri Nomor 8 Tahun 2020 tentang Perubahan Ketiga Anggaran Pendapatan dan Belanja Desa tahun anggaran 2020.

Disamping adanya perubahan Perdes, adnya permalasahan di Desa Tamanasri akibat pandemi Covid-19 yang mana diperkuat dari hasil wawancara dengan Ketua BPD Tamanasri, sebagai berikut:

"Hingga saat ini yang mana kegiatan bertatap muka dan berkerumun disatu tempat masih dibatasi, hal ini bertujuan agar meminimalisir penyebaran virus. Hal tersebut yang menyebabkan pelatihan dan pengembangan potensi terhadap anggota BPD baru yang telah dilantik pada 2 April 2020 hingga kini ditunda yang mana anggota BPD Tamanasri terdiri 7 orang anggota, 4 orang anggota diantaranya pernah menjabat di periode sebelumnya dan 3 orang lainnya belum pernah menjabat. Permasalahan baru pun muncul disebabkan sehingga hal ini dirasa kecakapan dan kekompakan kinerja tim dalam melakukan tugasnya oleh anggota baru masih perlu dioptimalkan". (Sumber: Wawancara dengan Ibu Arin Ketua BPD Tamanasri pada tanggal 29 September 2020)."

Adanya track record yang kurang baik di Desa Tamanasri pada tahun 2017-2018 serta berbagai dampak dari pandemi Covid-19 di Desa Tamanasri seperti yang telah terurai diatas merupakan alasan bagi peneliti guna mengamati serta membuktikan bagaimana proses pengawasan di Desa Tamanasri khususnya peran BPD dalam menjalankan tugas pengawasan. Maka, berdasarkan latar belakang permasalahan yang telah terurai diatas, penulis memiliki ketertarikan untuk memaparkan bagaimana peran Badan Permusyawaratan Desa dalam pelaksanaan fungsi pengawasan terkait pengelolaan APBDes. Sehingga, penulis melakukakan penelitian ini dengan memberi judul "Peran Pengawasan Badan Permusyawaratan Desa (BPD) Dalam Pengelolaan Anggaran Pendapatan dan Belanja Desa (APBDes) di Desa Tamanasri Kecamatan Pringkuku Kabupaten Pacitan.

\section{METODE}

Penelitian ini menggunakan jenis penelitian deskriptif. Pengertian penelitian deskriptif oleh Nawawi (2012:67) yaitu metode yang digunakan dalam menalaah suatu masalah dimasa sekarang yang berdasarkan fakta nyata, penelaahan masalah tersebut dilakukan dengan cara menggambarkan keadaan subyek atau obyek penelitian (orang, lembaga, masyarakat, dll). Disamping menggunakan jenis penelitian deskriptif, penelitian ini pun menggunakan metode pendekatan kualitatif. Sugiyono memaparkan bahwa metode kualitatif yaitu metode penelitian yang digunakan untuk meneliti kondisi obyek yang alamiah (sebagai lawannya ialah eksperimen) dimana peneliti ialah sebagai instrumen kunci, teknik pengumpulan data dilakukan secara trianggulasi (gabungan), analisis data bersifat induktif atau kualitatif dan hasil dari penelitian kualitatif lebih menekankan terhadap arti dari pada generalisasi, selain itu pada penelitian inipun berlandaskan pada filsafat postpositivisme. (Sugiyono, 2018:18). Sedangkan untuk teknik pengumpulan data yakni menggunakan wawancara terbuka yang bersifat terstruktur, observasi terstruktur serta dokumentasi.

Adapun dalam penelitian ini menggunakan beberapa sumber data, diantaranya: a) Sumber primer merupakan data yang diperoleh secara langsung dari objek yang 
diteliti. Sumber primer adalah sumber data yang "langsung memberikan" data kepada pengumpul data. (Sugiyono, 2015:137). b) Data Sekunder merupakan perolehan data yang dikumpulkan melalui sumber yang sudah ada sebelumnya. Sumber data sekunder ialah catatan atau dokumentasi perusahaan atau organisasi, publikasi pemerintah, analisis industri oleh media, situs web, internet dan seterusnya (Uma, 2011:76). Selain dalam penelitian ini menggunakan teknik pengambilan sample dengan cara purposive sampling yaitu teknik pengambilan sample yang man sumber datanya dipilih dengan pertimbangan dan tujuan tertentu (Sugiyono, 2015: 216)

Kajian penelitian ini, memaparkan tentang pelaksanaan peran pengawasan Badan Permusyawaratan Desa (BPD) dalam pengelolaan Anggaran Pendapatan dan Belanja Desa (APBDes) dimasa pandemi Covid-19 di Desa Tamanasri Kecamatan Pringkuku Kabupaten Pacitan dengan menggunakan teori proses pengawasan oleh Terry dalam buku Principles of Manajemen (Sukarna, 2011:116) dijelaskan berkaitan dengan proses pengawasan, yakni sebagai berikut;

1. Determining the standard or basis for control (menentukan standar atau dasar bagi pengawasan), yakni sebagai tolak ukur yang ingin dicapai. Dalam hal ini mencakup sebagai berikut:

a) Proses penetapan standar sebagai tolak ukur yang akan dicapai dimasa pandemi Covid-19 di Desa Tamanasri.

b) Standar peran pengawasan BPD Tamanasri terhadap APBDes pada masa pandemi Covid-19.

2. Measuring the performance (mengukur pelaksanaan), dalam hal ini mencakup sebagai berikut :

a) Keterlibatan BPD Tamanasri dalam pelaksanaan kinerja pengelolaan APBDes dimasa pandemi Covid-19.

b) Penilaian BPD Tamanasri terhadap pelaksanaan APBDes dimasa pandemi Covid-19

3. Comparing performance with the standard and ascerting the difference, it any (membandingkan pelaksanaan dengan standard dan temukan jika ada perbedaan)

a) BPD Tamanasri dalam membandingkan hasil pelaksanaan kerja dengan rencana yang ditetapkan.

b) Ada atau tidaknya perbedaan antara standar pengelolaan APBDes dengan pelaksanaan dilapangan di Desa Tamanasri dimasa pandemi Covid-19

4. Correcting the deviation by means of remedial action (perbaiki penyimpangan dengan cara-cara tindakan yang tepat). a) Ada atau tidaknya penyimpangan yang ditemukan selama melakukan pengawasan pengelolaan APBDes dimasa pandemi Covid-19 oleh BPD Tamanasri. Jika ada, seperti apa tindakan BPD Tamanasri dalam menyikapi dan melakukan perbaikan. Dan jika tidak ada bagaimana cara mempertahankan agar eksistensi tersebut dapat terjaga.

b) Tindakan BPD Tamanasri dalam melakukan pencegahan peyalahgunaan pengelolaan APBDes dimasa pandemi Covid-19.

Selain itu dalam penelitian ini menggunakan teknik analisis data Spradley. Model analisis data Spradley (Sugiyono, 2015:330) membaginya berdasarkan tahapan dalam penelitian kualitatif. Tahapan penelitian tersebut meliputi: a) Memilih situasi sosial (Place, Actor, Activity); b) Melaksanakan observasi partisipan; c) Mencatat hasil observasi dan wawancara; d) Melakukan observasi deskriptif; e) Melakukan analisis domain; f) Melakukan observasi terfokus; g) Melakukan analisis taksonomi, h) Melakukan observasi terseleksi; i) Analisis komponansial; j) Analisis tema; k) Temuan Budaya; 1) Menulis laporan penelitian kualitatif.

\section{HASIL DAN PEMBAHASAN}

Undang-Undang No 6 Tahun 2014 menyatakan, Badan Permusyawaratan Desa (BPD) merupakan lembaga yang melaksanakan fungsi pemerintahan dengan anggotanya ialah wakil dari penduduk berdasarkan keterwakilan wilayah dan ditetapkan secara demokratis. Mengacu pada Undang-Undang Nomor 6 Tahun (Undang-Undang Republik Indonesia No 6 Tahun 2014 Tentang Desa, 2014) tentang Desa Pasal 55 disebutkan bahwa BPD mempunyai fungsi yaitu: 1) membahas dan menyepakati Rancangan Peraturan Desa bersama Kepala Desa; 2) menampung dan menyalurkan aspirasi masyarakat desa; dan 3) melakukan pengawasan kinerja kepala desa.

Disisi lain peran BPD menjadi semakin urgent hal ini disebabkan adanya pandemi Covid-19 yang masih berlangsung di Indonesia. Adanya pandemi Covid-19 ini mengharuskan adanya perubahan yang terjadi pada APBDes yang mana sebelumnya telah dirancang dan disahkan. Adanya perubahan terhadap APBDes ini pun BPD terlibat secara tak langsung, yakni dengan cara melakukan pengawasan mengenai bagaimana mekanisme perubahan APBDes tersebut serta mengumpulkan aspirasi masyarakat desa. Berikut ini merupakan uraian dari peran pengawasan BPD dimasa pandemi Covid-19 di Desa Tamanasri Kecamatan Pringkuku Kabupaten Pacitan.

1. Determining the standard or basis for control (menentukan standard atau dasar bagi pengawasan); 
Dalam pengawasan BPD terhadap pengelolaan APBDes tentu harus memiliki sebuah standar untuk menunjang tercapainya target yang telah ditentukan sebelumnya. Ketika menetukan standar tersebut, suatu desa menyusun dan menetapkan Peraturan Desa (Perdes), yang mana menurut UU No 6 Tahun 2014 merupakan peraturan perundang-undangan desa yang ditetapkan oleh Kepala Desa setelah dibahas dan disepakati oleh BPD, Perdes tersebut tak lain ialah kerangka hukum dan kebijakan dalam melakukan penyelenggaraan pemerintahan desa serta pembangunan desa. Penyusunan APBDes harus benar-benar dirumuskan dengan bijak dan sesuai kebutuhan desa, hal ini bertujuan agar pembangunan desa dapat berjalan maksimal serta aspirasi masyarakat tersalurkan. Berikut ini merupakan proses penetapan standar yang terdapat di Desa Tamanasri:

\section{a) Proses penetapan standar sebagai tolak ukur yang akan dicapai dimasa pandemi Covid-19 di Desa Tamanasri oleh BPD Tamanasri.}

Pada kondisi pandemi Covid-19 yang masih berlangsug ini, banyak sekali berbagai keluhan dari masyarakat desa. Sedangkan menurut Putra (2019) sebagai wakil dari masyarakat sekaligus badan legislatif di tingkat desa diharapkan BPD dapat menjadi wadah politik bagi masyarakat desa, dengan demikian BPD diharapkan dapat menyalurkan ide dan gagasan dari masyarakat Dalam menampung aspirasi masyarakat tersebut dapat dilakukan melalui rapat BPD. Hal ini dikarenakan adanya rapat yang diselenggarakan BPD tersebut dapat dihadiri tokoh masyarakat, lembaga masyarakat maupun masyarakar desa. Partisipasi masyarakat ini diperlukan karena untuk membantu BPD dalam menganalisis permasalahan yang tengah terjadi di desa. Adapun syarat sahnya pengambilan keputusan ini ialah dengan tercapainya jumlah $50 \%+1$ jumlah anggota BPD. Namun disisi lain rapat ini akan disebut sah pula apabila memenuhi jumlah minimal yakni dua pertiga (2/3) dari jumlah anggota BPD yang hadir.

Berdasarkan hasil observasi di Desa Tamanasri, berikut ini merupakan proses penetapan perubahan APBDes sebagaimana yang telah dijelaskan oleh Sekdes Tamanasri pada saat melakukan wawancara pada tanggal 4 November, berikut ini merupakan prose penetapan APBDes:

1. Melakukan perundingan, yakni oleh pemerintah desa terkait pandemi Covid-19 di desa. Disini Pemerintah desa mempertimbangkan aspirasi masyarakat desa. Hal ini masyarakat dapat menyampaikan langsung ke pemerintah desa dan atau melalui BPD. Perlu penggaris bawahan yaitu dengan memperhatikan kondisi desa serta protokol Covid-19.

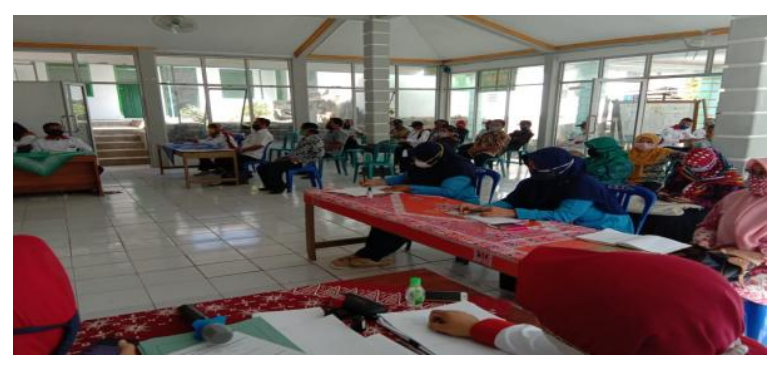

Gambar 2. Proses Penggalian aspirasi masyarakat melaui Musyawarah Desa (Sumber: Dokumentasi Desa Tamanasri, 2020)

2. Membentuk sebuah tim gugus tugas guna percepatan dalam penangan Covid-19 di desa. Hal ini didasakan atas arahan dan rekomendasi ketua gugus tugas percepatan penanganan Covid-19 kabupaten/kota. Berikut ini merupakan tim struktur tim gugus tugas percepatan penangan Covid-19 di Desa Tamanasri, yakni :

a. Ketua Satgas Covid-19 yang merupakan Kepala Desa Tamanasri,

b. Wakil Satgas Covid-19 yang merupakan Ketua BPD Tamanasri,

c. Anggota : perangkat desa, anggota BPD, kepala dusun, ketua RT, ketua RW, pendamping desa, bidan desa, tokoh agama, tokoh masyarakat, karang taruna, PKK, Kader Penggerak Masyarakat Desa (KPMD)

d. Mitra Desa Tamanasri yakni Babinkamtibmas, Babinsa, Pendamping Desa.

3. Melakukan peninjauan terhadap RKP Desa dan APBDes dikoordinasikan oleh sekretaris desa terkait respon desa terhadap pandemi Covid-19.

4. Jika hasil perubahan menyatakan tidak perlu diubah maka selanjutnya yaitu pelaksanaan kegiatan beserta anggaran. Namun jika hasil peninjauan tersebut perlu diubah, maka selanjutnya ialah melakukan penyusunan Rancangan Perubahan RKP Desa dan APBDes Tahun Anggaran (TA) 2020 dikoordinasikan oleh sekretasris desa guna dilakukan percepatan penanganan pandemi Covid19 (menambah kegiatan di luar bidang (5) yakni Bidang Penanggulangan Bencana, Darurat dan Keadaan Mendesak atau diluar bidang tersebut. Selanjutnya yaitu Musrenbangdes khusus Rancangan Perubahan RKP Desa dan APBDes TA 2020 pembahasan penambahan kegiatan di luar Bidang 5 dan atau kegiatan di bidang 5 terkait penanganan Covid-19 di desa. Setelah itu Penetapan 
Perubahan RKPDes dan APBDes TA 2020. Lalu melakukan pelaksanaan kegiatan anggaran.

5. Dengan melibatkan BPD, melalui Rapat Kerja Pemerintah Desa diselenggarakannya pertanggungjawaban kegiatan yang mana nantinya dituangkan dalam Berita Acara yang paling lama 1 bulan atau setelah berakhirnya masa Kondisi Luar Biasa (KLB) yang ditetapkan oleh Gugusan Tugas tingkat kabupaten/kota.

6. Penyampaian laporan pengeluaran anggaran kegiatan kepada bupati/walikota yang dilakukan oleh kepala desa, yang mana paling lambar 1 bulan atau setelah berakhirnya KLB

7. Kepala Desa melakukan penyampaian laporan pengeluaran anggaran kegiatan kepada Bupati/ Walikota paling lambat 1 bulan atau setelah berakhirnya KLB yang ditetapkan oleh Gugus Tugas tingkat Kabupaten/Kota.

8. Bupati/Walikota melakukan pembinaan dan pengawasan kepada Pemerintahan Desa melalui Organisasi Perangkat Daerah (OPD) yang terkait.

9. Bupati/Walikota melaporkan perkembangan kegiatan penanggulangan dan pencegahan wabah Cobvid-19 di desa kepada Menteri Dalam Negeri melalui Direktur Jenderal Binda Pemerintah Desa.

Dari pemaparan hasil observasi diatas dapat disimpullkan bahwa, dari proses yang telah terpapar sebelumnya, BPD Tamanasri beserta pemerintah desa yang turut menggandeng masyarakat desa telah melakukan kinerjanya dengan baik. Adanya penggalian aspirasi masyarakat yang telah dilakukan bersama dengan BPD Tamanasri merupakan langkah awal untuk menentukan perubahan peraturan APBDes Tamanasri, karena masyarakat dapat memebantu dalam menganalisis permasalahan yang terdapat di desa. Disisi lain tingkat partisipasi masyarakat Desa Tamanasri disini sudah cukup baik, terbukti dengan adanya pembentukan tim satgas Covid19, yang diketuai oleh kepala desa ini berguna untuk percepatan penangan dimasa pandemi Covid-19. Disini salah satu peran masyarakat desa yang bergabung dalam tim sukarelawan tersebut yaitu membantu pemerintah desa untuk pendataan masyarakat yang nantinya untuk keperluan bantuan yang akan disalurkan kepada masyarakat yang membutuhkan dan memenuhi syarat pendataannya.

Menurut penuturan Sekdes Tamanasri pada saat melakukan wawancara pada tanggal 4 November 2020, menyatakan:

Adanya sinergi yang dilakukan ditingkat desa tersebut nantinya akan berdampak hingga di tingkat kabupaten, yang mana jika ditingkat pemerintah desa sudah melakukan sesuai prosedur yang berlaku tersebut, maka akan mudah prosesnya ditingkat pemerintah kabupaten.

Dari pernyataan tersebut adanya penetapan standar sebagai tolak ukur dalam sesuatu yang ingin dicapai dimasa pandemi Covid-19, yang mana dimasa pandemi Covid-19 yang masih berlangsung ini mengakibatkan adanya perubahan terhadap Peraturan Desa APBDes Tamanasri yang sebelumnya ditetapkan. Adapun tujuan yang hendak dicapai pemerinthan Desa Tamanasri ini terkait adanya perubahan tersebut adalah keutamaan kebutuhan yang diperlukan dimasa pandemi Covid-19. Berikut merupkan perubahan Perdes Tamanasri dimasa pandemi Covid-19 sekaligus sebagai acuan atau tolak ukur BPD dalam melakukan pengawasan APBDes di Desa Tamanasri:

\section{b) Standar peran pengawasan BPD Tamanasri terhadap APBDes dimasa pandemi Covid-19.}

Selama pandemi Covid-19, Perdes APBDes Tamanasri telah mengalami sejumlah 3 kali perubahan. Hal ini dilatarbelakangi karena pemerintah pusat menganggarkan Bantuan Langsung Tunai Dana Desa (BLT DD) untuk masyarakat desa yang terdampak pandemi Covid-19. Sehingga pemerintah desa menyesuaikan perubahan dari pemerintah pusat tersebut dengan melakukan perubahan terhadap Perdes. Berikut rincian perubahan Perdes selama Covid-19 tersebut:

Tabel 3. Perubahan Perdes Tamanasri

\begin{tabular}{|c|c|}
\hline $\begin{array}{l}\text { Peraturan Desa } \\
\text { sebelum pandemi } \\
\text { Covid-19 di Desa } \\
\text { Tamanasri }\end{array}$ & $\begin{array}{l}\text { Perdes Tamanasri Nomor } 05 \text { Tahun } 2019 \\
\text { tentang Anggaran Pendapatan dan } \\
\text { Belanja Desa (APBDes) tahun anggaran } \\
\text { 2020. Merupakan Perdes awal untuk TA } \\
\text { 2020, dan sebelum terjadi Covid-19. } \\
\text { Tanggal pengesahan yaitu } 30 \text { Desember } \\
\text { 2019. }\end{array}$ \\
\hline \multirow[t]{3}{*}{ 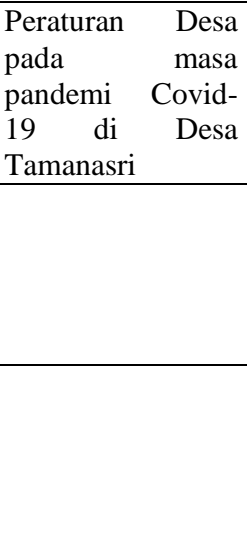 } & $\begin{array}{l}\text { a) Perdes Tamanasri Nomor } 4 \text { Tahun } \\
2020 \text { tentang Perubahan Pertama } \\
\text { Anggaran Pendapatan dan Belanja } \\
\text { Desa (APBDes) TA 2020. Disahkan } \\
\text { pada tanggal 13 Mei 2020. }\end{array}$ \\
\hline & $\begin{array}{l}\text { b) Perdes Tamanasri Nomor } 6 \text { Tahun } \\
2020 \text { tentang Perubahan Kedua } \\
\text { Anggaran Pendapatan dan Belanja } \\
\text { Desa (APBDes) TA 2020. Disahkan } \\
\text { pada tanggal 15 Juli 2020. }\end{array}$ \\
\hline & $\begin{array}{l}\text { c) Perdes Tamanasri Nomor } 8 \text { Tahun } \\
2020 \text { tentang Perubahan Ketiga } \\
\text { Anggaran Pendapatan dan Belanja } \\
\text { Desa (APBDes) TA 2020. Disahkan } \\
\text { pada tanggal 2 November 2020. }\end{array}$ \\
\hline
\end{tabular}

Sumber: Dokumen Desa Tamanasri, 2020

Perubahan Perdes tentang Anggaran Pendapatan dan Belanja Desa (APBDes) seperti yang terjadi di Tamanasri ini diperbolehkan jika ada kondisi khusus atau bencana yang berkepanjangan, contohnya yang 
terjadi saat ini yaitu pandemi virus Covid-19. Dengan adanya perubahan yang terjadi pada APBDes ini BPD harus memastikan sebelum pengesahan dan sesudah pengesahan.

Ketua BPD Tamanasri, menjelaskan jika BPD Tamanasri telah melakukan pengawasan sebelum pengesahan APBDes atau dengan nama lain pengawasan preventif yakni dengan cara melakukan pengecekan terhadap Rancangan Anggaran Pendapatan dan Belanja Desa (RAPBDes) yang didapatkan dari pemerintah desa yang kemudian diserahkan kepada $\mathrm{BPD}$, pengecekkan yang dilakukan BPD dengan cara melakukan rapat anggota BPD guna membahas RAPBDes, jika ditemukan hal yang kurang tepat dari oleh BPD maka BPD memberi sebuah catatan yang berisi masukan untuk diperbaiki oleh pemerintah desa, dan pemerintah desa berhak melakukan koordinasi dengan perangkat desa terkait catatan dari BPD tersebut. Setelahnya, jika semua sudah tidak ada hal yang perlu dibenahi maka BPD memberikan persetujuan dengan cara ketua BPD memberi tanda tangan terkait RAPBDes tersebut sehingga menjadi APBDes. Selain pengawasan preventif yang dilakukan BPD, pengawasan selama proses pelaksanaan yang sedang berlangsung atau disebut dengan in direct juga dilakukan oleh BPD dalam jangka waktu tertentu atau berkala. Hal ini bertujuan agar perencanaan yang telah dirancang dan disepakati sebelumnya dapat terealisasi tanpa ada tindak penyelewengan yang terjadi dilapangan. (Sumber: Ibu Arin, Ketua BPD Tamanasri, Wawancara 5 November 2020). Setelah melalui proses dan penentuan standar pengelolaan APBDes, maka selanjutnya yaitu melakukan pengukuran pelaksanaan:

\section{Measuring the performance (mengukur pelaksanaan);}

Dalam proses ini oleh Efendi (2014) dijelaskan bahwa pengukuran pelaksanaan kegiatan ini dilakukan secara berulang, yang mana dapat dilakukan melalui pengamatan, laporan, metode otomatis dan inspeksi pengujian (Ifani, 2018). Berdasarkan observasi di lapangan terkait pengukuran BPD dalam mengukur atau menilai kinerja pelaksanaan APBDes di Desa Tamanasri telah terlaksana. Perlunya pengawasan yang dilakukan pada suatu kegiatan yang akan di anggarkan, ditambah banyaknya melakukan perubahan terhadap APBDes. Peran pengawasan BPD disini ialah dilakukan dengan berlangsungnya (in direct) pelaksanaan proses tersebut secara berkala terkait pengelolaan APBDes dimasa pandemi Covid-19 ini yaitu memastikan anggaran yang telah ditetapkan sesuai dengan pelaksanaan di lapangan. Hal ini diperkuat melalui wawancara yang telah dilakukan peneliti dengan Sekretari BPD Tamanasri, sebagai berikut:
"BPD merupakan mitra pemerintah desa, sehingga pengawasan yang dilakukan oleh BPD bukan bersifat menjatuhkan, melainkan pengawasan yang bersifat memberikan masukan atau input yang dapat berdampak positif bagi keberlangsungan roda pemerintahan Desa Tamanasri. Jadi antara BPD dan kepala desa bersama-sama saling mengingatkan satu sama lain jika terjadi kekeliruan" (Sumber: Ibu Dian, Sekretaris BPD, Wawancara 5 November 2020).

Dari hasil wawancara tersebut dapat disimpulkan BPD Tamanasri serta pemerintah desa sudah melakukan sinergi yang baik serta menjalankan tupoksinya dengan baik selama kegiatan berlangsung. Idealnya pengukuran suatu pelaksanaan dilakukan atas dasar pengamatan yang dilakukan dalam jangka waktu tertentu serta bagaimana keterlibatan pengukur dalam mengukur pelaksanaan tersebut sehingga dapat pengukur kegiatan tersebut dapat menilai atau mengukur pelaksanaan tersebut. Dengan demikian dapat mencegah sesuatu yang sekiranya dapat menghambat jalannya kegiatan tersebut. Untuk lebih jelasnya berikut ini merupukan uraian hasil pengamatan terkait BPD Tamanari dalam melakukan pengukuran pelaksanaan kinerja pemerintah desa dalam mengelola APBDes:

\section{a. Keterlibatan BPD Tamanasri dalam pelaksanaan kinerja pengelolaan APBDes dimasa pandemi Covid-19.}

Keterlibatan pengukur dalam hal ini adalah BPD dalam mengukur pelaksanaan kegiatan. Dalam hal ini peran BPD hanya monitoring atau melakukan pengawasan saja di dalam pemerintahan desa. dari hasil wawancara dengan ketua BPD Tamanasri, yakni Ibu Arin. Berikut ini poin penting keterlibatan BPD Tamanasri:

a) Pada saat APBDes dikelola dilapangan oleh para pelaksana, maka BPD menindak dengan mengawasi semua kegiatan yang terjadi di lapangan, pengawasan ini dilakukan secara berkala. Dalam hal ini masyarakat juga dapat ikut serta dalam melakukan pengawasan kinerja pemerintah desa. Dengan demikian, jika terjadi komplain atau masukan dari masyarajat terkait kinerja pemerintah desa, BPD dapat mengawalnya, dan selanjutnya dapat dibahas dalam rapat anggota BPD yang nantinya akan disampaikan kepada pemerintah desa.

b) Selama pelaksanaan proses pengawasan berlangsung, BPD dapat memberikan saran jika pemerintah desa menyampaikan kesulitan dalam menangani suatu kegiatan realisasi APBDes dilapangan. Disamping pemberian saran, BPD pun dapat melakukan teguran kepada pelaksana pengelolaan APBDes, jika ditemukan tindakan yang kurang tepat, dalam hal ini teguran bersifat kekeluargaan. 
Dari poin-poin yang telah disebutkan oleh ketua BPD Tamanasri tersebut, peneliti dapat menarik kesimpulan terkait keterlibatan BPD Tamanasri selama proses pelaksanaan pengelolaan APBDes telah dilakukan dengan baik, terlebih dalam hal mengawal aspirasi masyarkat desa, yang mana hal tersebut merupakan salah satu peran BPD untuk masyarakat desa. Terkait hal tersebut BPD Tamanasri harus dapat meningkatakan kedekatannya dengan masyarakat desa, karena masyarakat desa secara tidak langsung juga dapat menjadi pengawas terkait kinerja pemerintah desa. Disisi lain BPD yang dapat memberikan teguran atau saran terhadap pemerintah desa disampaikan dengan cara kekeluargaan, hal ini dimaksud agar tidak timbul perselisihan atau kesalahpahaman yang timbul dari pihak BPD maupun pihak pemerintah Desa Tamanasri. Adanya teguran maupun saran yang diberikan BPD tersebut bertujuan untuk kinerja dalam pelaksanaan menjadi lebih baik.

\section{b. Penilaian BPD Tamanasri terhadap pelaksanaan APBDes dimasa pandemi Covid-19}

Keterlibatan BPD yang merupakan pengawasan terhadap pelaksanaan pengelolaan APBDes, maka selanjutnya BPD dapat menilai baik/ buruknya pelaksanaan yang telah dijalankan. Penilaian BPD terkait penyelenggaraan APBDes sangat diperlukan, jika nantinya ditemukan suatu hal yang kurang tepat selama proses penyelenggaraan APBDes dapat segera diatasi. Berikut ini merupakan penuturan dari Ketua BPD Tamanasri terkait penilaian terhadap pelaksanaan APBDes dimasa pandemi Covid-19.

"Kami (BPD Tamanasri) menilai kinerja penyelenggaraan APBDes sudah berjalan dengan semestinya. Kuncinya adalah tidak menyalahi aturan yang telah ditetapkan, karena dari pihak BPD dan pemerintah desa saling bersinergi satu sama lain. Disamping itu pemertintah Desa Tamanasri selama tahun penyelenggaraan ini karena adanya Covid-19, anggaran dana difokuskan untuk alokasi saranaprasarana kebutuhan APD sesuai protokol Covid19." (Sumber: Ibu Arin, Ketua BPD Tamanasri )

Berdasarkan penuturan dari ketua BPD tersebut, terkait alokasi dana yang digunakan untuk kebutuhan dimasa pandemi Covid-19 tersebut telah dimuat dalam APBDes bidang (5). Berikut ini merupakan anggaran yang terdapat pada bidang (5) dalam APBDes yakni Bidang Penanggulangan Bencana, Darurat dan Keadaan Mendesak Perdes perubahan ketiga tentang APBDes No 8 Tahun 2020 Desa Tamanasri :
Tabel 4. Rincian Anggaran Bidang Penanggulangan Bencana, Darurat dan Keadaan Mendesak Desa Tamanasri

\begin{tabular}{|c|c|c|c|}
\hline & \multicolumn{2}{|c|}{ Anggaran (Rp) } & \multirow{2}{*}{$\begin{array}{l}\text { Bertambah/ } \\
\text { (Berkurang) }\end{array}$} \\
\hline & Semula & Menjadi & \\
\hline $\begin{array}{l}\text { Bidang } \\
\text { Penanggulangan } \\
\text { Bencana, Darurat dan } \\
\text { Keadaan Desak }\end{array}$ & $\underline{2.254 .933,30}$ & $\underline{483.493 .933,30}$ & $\underline{481.239 .000,00}$ \\
\hline $\begin{array}{l}\text { Sub Bidang } \\
\text { penanggulangan } \\
\text { bencana }\end{array}$ & $\underline{\mathbf{0 , 0 0}}$ & $\underline{200.439 .000,00}$ & $\underline{200.439 .000,00}$ \\
\hline $\begin{array}{l}\text { Kegiatan } \\
\text { Penanggulangan } \\
\text { Bencana }\end{array}$ & 0,00 & $200.439 .000,00$ & $200.439 .000,00$ \\
\hline Belanja tidak terduga & 0,00 & $200.439 .000,00$ & $200.439 .000,00$ \\
\hline $\begin{array}{l}\text { Sub Bidang keadaan } \\
\text { mendesak }\end{array}$ & $\underline{2.254 .933,30}$ & $\underline{283.054 .933,30}$ & $\underline{280.800 .000,00}$ \\
\hline $\begin{array}{l}\text { Penanganan } \\
\text { Keadaan Mendesak }\end{array}$ & $2.254 .933,30$ & $283.054 .933,30$ & $280.800 .000,00$ \\
\hline Belanja tidak terduga & $2.254 .933,30$ & $283.054 .933,30$ & $280.800 .000,00$ \\
\hline
\end{tabular}

Sumber: Perdes-APBDes Tamanasri No 8 Tahun 2020

Dari data diatas yang merupakan penyaluran dana dimasa pandemi Covid-19 yang termuat dalam bidang Pendanggulangan Bencana, Darurat dan Keadaan Mendesak yang mana terdapat pada SubBidang Penanggulangan Bencana, berikut uraian alokasi dana guna memfasilitasi keperluan Desa Tamanasri dimasa pandemi Covid-19, diantaranya:

a. Disinfektan: Penyemprotan di lingkungan desa. Sedangkan untuk kawasasn keluar masuk wilayah dusun/ desa disediakan bilik penyemprotan disinfektan juga.

b. Pembuatan pos penjagaan di setiap dusun: melalui pos ini, pengunjung dari Desa Tamanasri atau dusun yang terdapat di Tamanasri sebelum memasuki kawasan Dusun/ Desa Tamanasri, wajib melakukan cek suhu badan dan sterilisasi serta mencuci tangan.

c. Alat Termo Gun: Alat untuk mengecek suhu badan tanpa melakukan kontak fisik ini disediakan di kantor Desa Tamanasri.

d. Ditiap fasilitas umum di dusun maupun desa seperti: kantor desa, PAUD, posyandu, Polindes, sekolah, taman, lapangan, sarana ibadah,dan lain-lain harus dilakukan sterilisasi.

e. Memfasilitasi peralatanmcuciktangan, seperti: (wastafel) di beberapa lokasi desa beserta sabun cucintangan;

f. Melakukan penyuluhan dan pendataan warga desa, sehingga akan diketahui mana warga yang terindikasi Covid-19 dan tidak dan langkah selanju tnya yaitu dapat melakukan karantina terhadap warga yang terindikasi Covid-19. Di Desa Tamanasri sendiri terdapat 2 orang yang positif Covid-19, namun pada tanggal 3 Desember dan 5 Desember, keduanya telah dinyatakan bebas dari Covid-19

g. Bantuan Pangan (sembako) bagi keluarga yang terkena Covid-19, karena 2 pasien Covid-19 di Desa 
Tamanasri merupakan dari keluarga yang brbeda, masing-masing keluarga mendapat bantuan sembako dari pemerintah Desa Tamanasri.

h. Bagi masyarakat yang melakukan karatina mandiri telah terealisasikan pembagian sembakonya.

i. Jika ada warga yang meninggal karena Covid-19 maka dillakukan pemakaman sesuai protokol Covid19. Di Desa Tamanasri terdapat satu warga yang meninggal dan dimakamkan sesuai protokol Covid19. (Sumber: Dokumen Desa Tamanasri, 2020)

Selain Sub-Bidang Penanggulangan Bencana, terdapat Sub-Bidang Keadaan Mendesak, yang mana didalamnya terdapat uraian terkait Bantuan Langsung Tunai Dana Desa (BLT-DD). Berikut ini ialah uraian dana terkait BLT-DD untuk masyarasat Desa Tamanasri:

Tabel 5. Penerima Bantuan Langsung Tunai Dana Desa (BLT DD) I, II, III di Desa Tamanasri

\begin{tabular}{|c|c|c|c|}
\hline $\begin{array}{c}\text { Tahap } \\
\text { ke- }\end{array}$ & $\begin{array}{c}\text { Jumlah } \\
\text { Penerima } \\
\text { Manfaat } \\
\text { BLT-DD }\end{array}$ & $\begin{array}{c}\text { Jumlah } \\
\text { yang } \\
\text { diterima } \\
\text { (Rp) }\end{array}$ & Kurun waktu \\
\hline 1 & 78 & 600.000 & $\begin{array}{c}3 \text { bulan (April, Mei, } \\
\text { Juni) }\end{array}$ \\
\hline 2 & 78 & 300.000 & $\begin{array}{c}3 \text { bulan (Juli, Agust, } \\
\text { Sept) }\end{array}$ \\
\hline 3 & 78 & 300.000 & $\begin{array}{c}3 \text { bulan (Okt, Nov, } \\
\text { Des) }\end{array}$ \\
\hline
\end{tabular}

Sumber: Dokumen Desa Tamanasri, 2020

Penyaluran BLT DD di Desa Tamanasri pada tahap 1 disalurkan pada bulan April. Pada tahap 1 masingmasing pada bulan April, Mei dan Juni disalurkan sebesar Rp 600.000/penerima manfaat. Perbedaan jumlah uang yang diterima pada tahap 1 dengan tahap II dan III berbeda karena dari pemerintah desa menyesuaikan yang dianggarkan dari pemerintah pusat yakni melalui menteri keuangan yang dimuat pada Peraturan Menteri Keuangan No 156/PMK 07 /2020.

Sebelum menerima bantuan tersebut, calon penerima manfaat terlebih dahulu dilakukan tahap survey oleh Tim Relawan Covid-19 yang mana sebelumnya telah ditetapkan. Tim tersebut merupakan warga Desa Tamanasri yang tidak menjabat di pemerintahan Desa Tamanasri. Dalam tahap survei tersebut haeus memenuhi syarat yakni dari masyarakat desa yang bersangkutan dan keluarga miskin atau tidak mampun serta tidak dalam menerima bantuan lain seperti: Kartu Sembako, Program Keluarga Harapan $(\mathrm{PKH})$, dan Kartu PrKerja. Dalam peraturan juga menjelaskan apabila masih terdapat sisa dana, maka kepala desadapat menggunakan sisa tersebut untuk program percepatan penanganan pandemi Covid-19.

Seperti penuturan yang telah disampaikan oleh ketua BPD Tamanasri serta data yang telah tersaji sebelumnya dapat disimpulkan penilaian BPD terhadap pelaksanaan APBDes telah dilaksanakan sesuai dengan sebagaimana mestinya, bahwa alokasi dana selama pandemi Covid-19 sudah berjalan dengan baik, hal ini dikarenakan:

a) Pemerintah desa mengalokasikan dana desa dengan baik terkait kebutuhan dimasa pandemi Covid-19.

b) Masyarakat telah menerima dana BLT-DD, BPD menilai penerima manfaat BLT-DD sudah tepat sasaran karena sebelumnya telah dilakukan survei oleh tim relawan covid-19 yang independen, yakni masyarakat desa stempat yang bukan berasal dari perangkat desa.

c) Disamping dana BLT-DD yang diterima oleh masyarakat miskin yang telah memenuhi syarat penerima BLT-DD, adapun untuk keluarga yang terindikasi positif Covid-19 diberikan bantuan sembako, yang dinamakan sembako karantina mandiri. Di desa Tamanasri telah ada 2 orang dari keluarga yang berbeda yang terindikasi positif Covid-19 sehingga keluarga dari 2 pasien positif tersebut di karantina dan diberikan bantuan sembako dari pemerintah Desa Tamanasri. Kini 2 pasien positif Covid-19 tersebut pada awal desember tealh dinyatakan negatif Covid-19

Dari data dan penjelasan yang telah terurai diatas, mulai dari segi peran keterlibatan yakni pengawasan dari pihak BPD Tamanasri dalam pelaksanaan pengelolaan APBDes yang mana dari pengawasan tersebut BPD Tamanasri dapat menilai atau mengukur pelaksanaan pengelolaan APBDes selama pandemi Covid-19, yakni secara keseluruhan sudah memenuhi kriteria yang baik karena alokasi dana telah tersalurkan untuk kebutuhan dimasa pandemi Covid-19, baik itu sarana-prasarana hingga bantuan untuk masyarakat yan terdampak Covid-19.

\section{Comparing performance with the standard and ascerting the difference, it any (membandingkan pelaksanaan dengan standard dan temukan jika ada perbedaan);}

Setelah melakukan penilaian terhadap pelaksanaan, maka hal selanjutnya yaitu BPD Tamanasri dalam menjalankan pengawasannya dapat mengetahui dapat membandingkan kinerja pada saat pelaksanaan pengelolaan APBDes dilapangan dengan standar pengelolaan APBDes yang sebelumnya telah disepakati BPD Tamanasri dan pemerintah Desa Tamanasri, selain itu BPD juga dapat mengetahui terkait ada atau tidaknya perbedaan saat pengawasan terhadap 
pengelolaan APBDes berlangsung, berikut ulasan terkait hal tersebut:

\section{a. BPD Tamanasri dalam membandingkan hasil pelaksanaan kerja dengan rencana yang ditetapkan.}

Dalam hal ini usaha yang dilakukan BPD ialah dengan cara melakukan laporan pelaksanaan APBDes bersama Kepala Desa guna melakukan evaluasi kinerja atau pelaksanaan pengelolaan APBDes secara keseluruhan. Disamping itu di Desa Tamanasri sendiri, BPD beserta masayrakat desa saling bersinergi dalam melakukan pengawasan terhadap kinerja pemerintahan desa. Karena aspirasi masyarakat tidak hanya dilakukan . Dan nantinya secara keseluruhan hasil dari pelaksanaan pengelolaan APBDes. Selain itu pelaksanaan pengelolaan APBDes ini akan dilakukan evaluasi oleh Kepala Desa Tamanari beserta BPD. Berikut diantaranya:

1) Laporan Pertanggungjawaban Realisasi Pelaksanaan APBDes Tahun Anggaran 2019 telah dilakukan pada Januari 2020, yang mana pada realisasi tersebut telah dibuatkan Peraturan Desa No 1 Tahun 2020. Berikut ini adalah garis besar laporan realisasi tahun anggaran 2019 di Desa Tamanasri tersebut:

Tabel 6. Laporan Pertanggungjawaban APBDes 2019

\begin{tabular}{|l|r|}
\hline 1. Pendapatan Desa & \multicolumn{1}{|c|}{ Jumlah (Rp) } \\
\hline a. Pendapatan Asli Desa & $16.000 .000,00$ \\
\hline b. Pendapatan Transfer & $1.645 .447 .156,51$ \\
\hline c. Lain-lain Pendapatan yang sah & $600.000,00$ \\
\hline Jumlah Pendapatan & $\mathbf{1 . 6 6 2 . 0 4 7 . 1 5 6 , 5 1}$ \\
\hline 2. Belanja Desa & \\
\hline $\begin{array}{l}\text { a. Bidang Peyelenggaraan Pemerintahan } \\
\text { Desa }\end{array}$ & $617.602 .206,51$ \\
\hline b. Bidang Pelaksanaan Pembangunan Desa & $999.984 .771,00$ \\
\hline c. Bidang Pembinaan Kemayrakatan Desa & $30.704 .000,00$ \\
\hline $\begin{array}{l}\text { d. Bidang Pemberdayaan Masyarakatan } \\
\text { Desa }\end{array}$ & $21.244 .000,00$ \\
\hline $\begin{array}{l}\text { e. Bidang Penanggulangan Bencana, } \\
\text { Keadaan Darurat dan Mendesak }\end{array}$ & $2.254 .933,30$ \\
\hline Jumlah Belanja & $\mathbf{1 . 6 7 1 . 7 8 9 . 9 1 0 , 8 1}$ \\
\hline 3. Pembiayaan Desa & $9.742 .754,30$ \\
\hline a.Penerimaan Pembiayaan & 0,00 \\
\hline b.Pengeluaran Pembiayaan & $\mathbf{9 . 7 4 2 . 7 5 4 , 3 0}$ \\
\hline Selisih (3.a- 3.b) & 0,00 \\
\hline $\begin{array}{l}\text { Sisa Lebih/ Kurang) Perhitungan } \\
\text { Anggaran }\end{array}$ & 0,00 \\
\hline \multicolumn{1}{|c|}{ Selisih Pembiayaan setelah perubahan } \\
\hline
\end{tabular}

Sumber: Laporan Realisasi APBDes Tamanasri TA 2019

Dari data diatas disimpulkan bahwa pendapatan desa yang sejumlah 1.662.047.156,51 dengan total pengeluaran sejumlah 1.671.789.910,81 sehingga mengalami defisit sejumlah $\mathbf{9 . 7 4 2 . 7 5 4 , 3 0}$ dan menerima pembiayaan sebesar $\mathbf{9 . 7 4 2 . 7 5 4 , 3 0}$ pula, yang mana dananya dapat diperoleh dari: SiLPA tahun anggaran sebelumnya, Pencairan Dana Cadangan atau Hasil Penjualan Kekayaan Desa yang Dipisahkan.

2) Sementara itu untuk tahun anggaran 2020 belum ada terkait laporan realisasinya, karena Desa Tamanasri akan menyelenggarakan laporan realisasi pertanggungjawaban APBDes tersebut di bulan Januari 2021 mendatang. Dengan demikian dalam tahun berjalan ini BPD Tamanasri dapat membandingkannya melalui Rencana Anggaran Biaya pada APBDes, karena telah 3 kali mengalami perubahan. Maka BPD Tamanasri harus benar-benar memastikan alokasi dana tersebut dengan benar. Dan hal ini telah dilakukan oleh BPD Tamanasri, yang mana telah memastikan antara anggaran atau standar kelola yang telah disepakati bersama pemerintah desa dapat berjalan sesuai yang ditentukan tersebut.

\section{b. Ada atau tidaknya perbedaan antara standar pengelolaan APBDes dengan pelaksanaan dilapangan di Desa Tamanasri dimasa pandemi Covid-19.}

Dari penuturan sekretaris BPD Tamanasri, menyatakan tidak ditemukan perbedaan yang signifikan antara perencanaan atau standar yang ditentukan dengan pelakasanaan pengelolaan APBDes Tamanasri (Wawancara pada tanggal 4 November). Disisi lain dimasa pandemi Covid-19 seperti data Tabel 5 yang telah disajikan sebelumnya, perbedaan hanya terdapat pada saat perubahan APBDes yaitu terletak pada anggaran BLT-DD antara tahap I dengan tahap II dan III berbeda hal ini disebabkan telah dianggarkan oleh pemerintah pusat (Peraturan Menteri Keuangan No Nomor 156/PMK.07 /2020) dan pemerintah desa hanya menjalankan sesuai aturan tersebut.

Dapat dilihat dalam Tabel 3, jika perubahan Perdes APBDes Tamanasri telah mengalami perubahan Perdes APBDes sebanyak tiga kali. Namun ketika direalisasikan dari perubahan pertama hingga perubahan ketiga Perdes APBDes Tamanasri tidak ditemukan perbedaan antara yang dianggarkan dengan yang direalisasikan. Dengan ini BPD Tamanasri telah melakukan tupoksinya dengan baik karena telah memastika tidak terjadinya perbedaan pada saat realisasi pengelolaan APBDes berlangsung. Karena masyrakat telah menerima dana BLT tersebut sesuai yang diatur dalam peraturan menteri keuangan, yakni Tahap 1 diterima Rp 600.000 tiap bulan April sampai Juni. Sedangkan tahap II dan III masyarakat menerima dana sebesar Rp 300.000 dari bulan Mei hingga Desember. 


\section{Correcting the deviation by means of remedial action (perbaiki penyimpangan dengan cara-cara tindakan yang tepat).}

Penyimpangan ada karena tidak adanya ketidakjujuran dan akuntabilitas legal. Namun jika kejujuran dan akuntabilitas legal telah benar-benar diterapkan dalam pengelolaan dana sesuai dengan pelaksanaan musyawarah desa sebagai sarana pengusulan kinerja dalam pemerintahan desa maka kinerja tersebut dapat telah berjalan sesuai keputusan bersama dan dapat dipertanggungjawabkan dengan baik (Elviana dan Niswah, 2018). Seperti yang dipaparkan Ketua BPD Tamanasri dan Sekretaris BPD Tamanasri menyatakan:

"Tidak ada penyimpangan selama proses berlangsungnya pelaksanaan pengelolaan APBDes dimasa pandemi Covid-19. Dalam wawancara dengan Ketua BPD Tamanasri, menambahkan jika semua terkendali dan berjalan sesuai rencana yang ditentukan. Selain itu adanya BPD yang memberikan arahan jika terjadi tindakan yang kurang tepat dapat mencegah terjadinya hal-hal yang menyeleweng di Desa Tamanasri selama pengelolaan APBDes berlangsung". (Sumber: Ketua dan Sekretaris BPD Tamanasri Wawancara 5 November 2020).

Dari hasil wawancara dengan Ketua BPD Tamanasri diatas memperoleh hasil yakni, tidak adanya penyimpangan yang terjadi. Dengan demikian, BPD Tamanasri harus mempertahankan eksistensi ini bersama dengan pemerintah Desa Tamanasri selaku pelaksana kegiatan pengelolaan APBDes. Hal tersebut dapat dilakukan dengan cara melakukan pencegahan agar tidak terjadi penyimpangan atau penyelewengan dilapangan dikemudian hari. Berdasarkan perolehan data observasi dan wawancara dengan ketua BPD pada tanggal 5 November 2020, berikut merupakan langkah pencegahan dari pihak BPD Tamanasri yaitu :

a) Melakukan teguran jika dari pihak penyelenggara APBDes (dalam hal ini adalah pemerintah desa) melakukan tindakan yang kurang tepat. Teguran tersebut bersifat kekeluargaan dan tidak bersifat menjatuhkan. Hal ini disebabkan BPD dan kepala desa adalah mitra dalam pemerintahan desa. Sehingga hubungan baik harus berjalan dengan komunikasi yang baik pula, dengan demikan teguran yang bersifat kekeluargaan ini akan menghindarkan dari konflik antar dua pihak.

b) Selain itu, BPD Tamanasri pun melakukan pengawasan secara berkala (bisa dilakukan dua minggu sekali atau dua kali) guna memantau kegiatan pelaksanaan pengelolaan APBDes di lapangan. Dengan begitu, akan mencegah terjadinya penyelewengan pelaksanaan pengelolaan APBDes dan dapat mencapai target yang telah ditentukan sebelumnya.

\section{PENUTUP}

\section{Simpulan}

Seperti yang terdapat dalam hasil dan pembahasan, maka dapat diambil kesimpulan bahwa selama pandemi ini telah terjadi sebanyak 3 kali perubahan terhadap Perdes APBDes Tamanasri. Sehingga hal ini menjadi sorotan penting terkait peran pengawasan BPD dalam pelaksanaan pengelolaan APBDes. Adanya perubahan ini disebabkan terdapat bantuan dana dari pemerintah pusat untuk masyarakat yang terdampak pandemi Covid-19 yang memenuhi syarat yakni diantaranya: masyarakat miskin yang tidak sedang menerima bantuan lain yang mana dilakukan survei oleh tim survei relawan covid-19 di Desa Tamanasri.

Adanya hal tersebut melalui penelitian ini, peneliti menggunakan teori yang dikemukakan oleh Terry, yakni: Determining the standard or basis for control (menentukan standar atau dasar bagi pengawasan), yakni sebagai tolak ukur yang ingin dicapai. Dalam hal ini mencakup sebagai berikut: Proses penetapan APBDes terkait perubahan APBDes pada masa pandemi Covid-19 di desa Tamanasri. Selama proses penetapan ini berlangsung, BPD mengumpulkan aspirasi masyarakat desa, terlebih keinginan masyarakat apa dan nantinya dipertimbakan tingkat urgensinya. Standar peran pengawasan BPD Tamanasri terhadap APBDes pada masa pandemi Covid-19. Terhitung 3 kali perubahan Perdes APBDes selama pandemi Covid19 di Desa Tamanasri. Dan Perdes inilah nantinya dijadikan acuan atau standar bagi BPD dalam melakukan pengawasan pelaksanaan pengelolaan APBDes.

Measuring the performance (mengukur pelaksanaan), dalam hal ini mencakup sebagai berikut : Keterlibatan BPD Tamanasri dalam pelaksanaan kinerja pengelolaan APBDes dimasa pandemi Covid-19. Dalam hal ini BPD hanya monitoring atau melakukan pengawasan saja di dalam pemerintahan desa. Penilaian BPD Tamanasri terhadap pelaksanaan APBDes dimasa pandemi Covid-19. Hasilnya yaitu BPD Tamanasri menilai kinerja penyelenggaraan APBDes sudah berjalan dengan semestinya, karena dari pihak BPD dan pemerintah desa saling bersinergi satu sama lain.

Comparing performance with the standard and ascerting the difference, it any (membandingkan pelaksanaan dengan standard dan temukan jika ada perbedaan). BPD Tamanasri dalam membandingkan hasil pelaksanaan kerja dengan rencana yang ditetapkan. Yakni dengan cara melakukan laporan pelaksanaan APBDes bersama Kepala Desa guna melakukan evaluasi kinerja atau pelaksanaan pengelolaan APBDes secara keseluruhan. Dan hasilnya yaitu Tidak ada perbedaan yang signifikan antara perencanaan atau 
standar yang ditentukan dengan realisasi pengelolaan APBDes di Tamanasri.

Correcting the deviation by means of remedial action (perbaiki penyimpangan dengan cara-cara tindakan yang tepat). Hasilnya yaitu: tidak ditemukan penyimpangan di Desa Tamanasri. Semua terkendali dan berjalan sesuai rencana yang ditentukan. Tindakan BPD Tamanasri dalam melakukan pencegahan peyalahgunaan pengelolaan APBDes dimasa pandemi Covid-19. Yakni dengan cara mengawasi dan mengevaluasi kinerja pengelolaan APBDes.

\section{Saran}

Berdasarkan kesimpulan yang telah diuraikan diatas, maka peneliti dapat memberikan saran sebagai berikut:

a. Pentingnya komunikasi, antar anggota BPD Tamanasri perlu menjalin komunikasi yang baik antar anggotanya. Selain itu, BPD perlu meningkatkan pula jalinan komunikasi yang baik dengan pemerintah desa dan perangkatnya. Sehingga pada saat melakukan kinerjanya tidak ada rasa sungkan yang menjadi penghalang.

b. Pentingnya menjalin kedekatan dengan masyarakat desa, sehingga dalam hal ini BPD Tamanasri perlu lebih mendekatkan diri dengan masyarakat Desa Tamanasri. Hal ini disebabkan aspirasi masyarakat penting dalam berlangsungnya roda pemerintahan desa. Dan fungsi BPD selain pengawasan dalam pemerintahan desa yaitu mengumpulakn aspirasi masyarakat desa, maka dari itu pentingnya BPD Tamanasri dalam mengayomi dan dekat dengan masyarakat desa.

c. Disebabkan masih dimasa pandemi Covid-19 diharapkan BPD Tamanasri maupun pemerintah desa tetap mematuhi protokol kesehatan. Pertemuan atau rapat secara langsung alangkah baiknya dibatasi dan bisa melalui media sosial atau online.

d. BPD Tamanasri harus dapat memastikan transparansi kinerja pemerintah desa kepada masyarakat dengan benar dan juga diiringi akuntabilitas yang tinggi.

e. Mempertahankan hubungan baik dengan pemerintah desa, jika ada suatu hal yang sekiranya dapat menghamabt berlangsungnya kinerja pemerintahan desa harus ditindak dengan cepat agar tidak menganggu berlangsungnya pelaksanaan suatu kegiatan.

\section{Ucapan Terima Kasih}

Penulis mengucapkan terima kasih kepada :

1. Dosen Pembimbing Muhammad Farid Ma'ruf, S.Sos, M.AP, Dosen Penguji yakni Eva Hany Fanida, S.AP., M.AP dan Fitrotun Niswah, S.AP., M.AP. yang telah membimbing sekaligus mengarahkan penulis selama proses penyusunan penilitian ini sehingga dapat diselesaikan dengan baik.

2. Badan Permusyawaratan Desa (BPD) Tamanasri, Pemerintah Desa Tamanasri, dan masyarakat Desa Tamanasri yang telah menerima penulis untuk melakukan penelitian di Desa Tamanasri serta membimbing dan membantu penulis selama proses penelitian ini sehingga dapat diselesaikan dengan baik.

\section{Daftar Pustaka}

Abas, A. (2017). Urgensi Etika Dalam Tata-Kelola Pemerintahan (Governance). JPSI (Journal of Public Sector Innovations), 1(2), 79. https://doi.org/10.26740/jpsi.v1n2.p79-89

Dekker, H., Donada, C., Mothe, C., \& Nogatchewsky, G. (2018). Boundary spanner relational behavior and inter-organizational control in supply chain relationships. Industrial Marketing Management, 77(February), $143-154$. https://doi.org/10.1016/j.indmarman.2018.11.010

DISKOMINFO. (2020). Data Pantauan COVID-19 Pacitan. Satuan Gugus Tugas Percepatan Penanganan COVID-19 Kabupaten Pacitan. https://covid19.pacitankab.go.id/

Elviana, N., \& Niswah, F. (2020). Akuntabilitas Aparatur Desa Dalam Pengelolaan Dana Desa Tahun Anggaran 2018 (Studi Kasus di Desa Karangrejo Kecamatan Bancar. Publika, Vol 8, No. https://jurnalmahasiswa.unesa.ac.id/index.php/publi $\mathrm{ka} /$ article/view/32190

Ifani, H. N. (2018). Pengawasan Kinerja Pemerintah Desa Oleh Badan Permusyawaratan Desa (Bpd) Di Kantor Desa Karangampel Kecamatan Baregbeg Kabupaten Ciamis. Journal of Chemical Information and Modeling, 53(9), 1689-1699.

Ihsanuddin. (2018). ICW: Ada 181 Kasus Korupsi Dana Desa, Rugikan Negara Rp 40,6 Miliar Halaman all Kompas.com. Kompas. https://nasional.kompas.com/read/2018/11/21/19000 481/icw-ada-181-kasus-korupsi-dana-desa-rugikannegara-rp-406-miliar?page $=$ all

KEMENDAGRI. (2018). Permendagri Nomor 20 Tahun 2018 Tentang Pengelolaan Keuangan Desa. Kementerian Dalam Negeri Republik Indonesia.

KEMENKESRI. (2020). Pedoman kesiapan menghadapi COVID-19 (Vol. 3, hal. 1-115). Kementerian Kesehatan Republik Indonesia.

KEMENKEURI. (2020). Perubahan Ketiga atas Peraturan Menteri Keuangan Nomor 205 / PMK.07 / 2019 tentang Pengelolaan Dana Desa (hal. 1-9). Kementerian Keuangan Republik Indonesia. https://peraturan.bpk.go.id/Home/Details/149354/p mk-no-156pmk072020

Lonthor, A. (2018). Otonomi Desa Dan Kesejahteraan Masyarakat Negeri Batu Merah Pasca Undang- 
Undang Nomor 6 Tahun 2014 Tentang Desa (Prespektif Hukum Progressif). Fakultas Syariah dan Ekonomi Islam IAIN Ambon, XIV No. 1. https://doi.org/10.33477/thk.v14i1.572

Mardiyah, S. A., \& Nurlinah. (2019). Analisis Peran Badan Permusyawaratan Desa (BPD) Dalam Penyelenggaraan Pemerintahan Di Desa Pao Kecamatan Tombolopao Kabupaten Gowa. Jurnal Ilmu Pemerintahan, 12(2), 108-115.

Nawawi, H. (2012). Metode Penelitian Bidang Sosial. Yogyakarta: Gajah Mada University Press.

Nitsae, O. G., Nurkholis, \& Purwanti, L. (2020). UPAYA MINIMALISASI KECURANGAN YANG TERJADI PADA KABUPATEN TIMOR TENGAH SELATAN. JPSI (Journal of Public Sector Innovations), Vol 4, No, 75-83.

Pangestika, M. W. (2019). Peran Badan Permusyawaratan Desa dalam pengawasan Anggaran Pendapatan dan Belanja Desa berdasarkan UU No. 6 Tahun 2014 tentang Desa. Jurnal Ekonomi dan Kebijakan (JEJAK), 6, 1-28. https://journal.unnes.ac.id/sju/index.php/islrev/articl e/download/38434/15841

PERDA. (2019). Peraturan Daerah Kabupaten Pacitan Nomor 3 Tahun 2019. Pemkab Pacitan. http://www.ghbook.ir/index.php?name= فرهن و هاى رسانه نوين\&option=com_dbook\&task=readonline\&book_i $\mathrm{d}=13650$ \&page $=73 \&$ chkhashk=ED9C9491B4\&Ite mid=218\&lang=fa\&tmpl=component

Polat, Z. A., \& Alkan, M. (2020). The role of government in land registry and cadastre service in Turkey: Towards a government 3.0 perspective. Land Use Policy, 92(January 2019), 104500. https://doi.org/10.1016/j.landusepol.2020.104500

PP. (2014). Peraturan Pemerintah Republik Indonesia No 43 Tahun 2014 Tentang Peraturan Pelaksanaan Undang-Undang No 6 Tahun 2014 Tentang Desa. Jakarta: Presiden Republik Indonesia. http://journal.stainkudus.ac.id/index.php/equilibrium /article/view/1268/1127

Pratama, B. (2019). Sudah Berapa Kades di Jatim yang Korupsi Dana Desa. Surabaya: Jatimnet.com. https://jatimnet.com/sudah-berapa-kades-di-jatimyang-korupsi-dana-desa

Puspitasari, R., \& Ma'ruf, M. F. (2018). Pengelolaan Anggaran Pendapatan Dan Belanja Desa( APBDES ) ( Studi kasus di Desa Mojogede Kecamatan Balongpanggang Kabupaten Gresik ) Rahayu Puspitasari. Jurnal Publika, Vol 6-No.6, 1-7. https://jurnalmahasiswa.unesa.ac.id/index.php/publi $\mathrm{ka} /$ article/view/23493/21477

Putra, A. A., \& dkk. (2019). Analisis kinerja badan permusyawaratan desa (BPD) dalam menampung dan menyalurkan aspirasi masyarakat di desa pemogan kecamatan denpasar selatan. Fakultas
Hukum Universitas Udayana, Vol 7-No, 1-11. https://ojs.unud.ac.id/index.php/Kerthanegara/article /view/49736/29547

Rois, R. F., \& Fanida, E. H. (2016). Akuntabilitas Penggunaan Dana Desa Dalam Pelaksanaan Pembangunan Desa Dan Pemberdayaan Masyarakat Desa. Jurnal Akuntansi, 1-7.

Roza, D., \& S, L. A. (2017). Peran Badan Permusyawaratan Desa di Dalam Pembangunan Desa dan Pengawasan Keuangan Desa. Padjajaran Jurnal Ilmu Hukum, 4(26), 606-624. https://doi.org/https://doi.org/10.22304/pjih.v4n3.a1 0

Rozuqi, N. (2020). Tahapan Perubahan APBDes. Simpledesa.

https://www.simpeldesa.com/blog/tahapanperubahan-apbdes/1997/

Samsirin. (2015). Konsep Manajemen Pengawasan dalam Pendidikan Islam. At-Ta'dib, Vol. 10. N, 341360.

https://ejournal.unida.gontor.ac.id/index.php/tadib/ar ticle/download/461/418

Sugiyono. (2015). Metode Penelitian Kuantitatif, Kualitatif dan R\&D. In Alfabetta (22 ed., hal. 334). Bandung: Alfabeta.

Sugiyono. (2018). Metode Penelitian Kuantitatif, Kualitatif dan $R \& D$ (hal. 18). Bandung: Alfabetta.

Sukarna. (2011). Dasar-Dasar Manajemen (hal. 116). CV Mandar Maju.

Sumbo, D. (2018). Terjerat Korupsi, Mantan Kades Taman Asri Dibui - Berita Jurnal. BeritaJurnal.com. http://beritajurnal.com/terjerat-korupsi-mantankades-taman-asri-dibui/

Uma, S. (2011). Metodologi Penelitian untuk Bisnis, Edisi 4. Jakarta: Salemba Empat.

Undang-Undang Republik Indonesia No 6 Tahun 2014 Tentang Desa. (2014). Jakarta: Presiden Republik Indonesia. https://doi.org/10.1145/2904081.2904088

Watts, J. D., Tacconi, L., Irawan, S., \& Wijaya, A. H. (2019). Village transfers for the environment: Lessons from community-based development programs and the village fund. Forest Policy and Economics, 108(June 2018), 3. https://doi.org/10.1016/j.forpol.2019.01.008 
Publika. Volume 9 Nomor 2 Tahun 2021, 255-270 